\title{
The Formation Environment of K-feldspar Porphyritic Granite from E-Mount, Yunnan
}

\author{
Jin $\mathrm{Hu}$, Shitao Zhang ${ }^{*}$ and Ying Zhang \\ Faculty of Land Resource Engineering of Kunming University of Science and Technology, Kunming, Yunnan \\ *Corresponding author
}

\begin{abstract}
E-mount granite Pluton is located at the southwest part of Yangtze plate. To understand the formation environment of K-feldspar porphyritic granite from E-Mount, approaches such as major and trace element analysis and zircon LA- ICP-MS $\mathrm{U}-\mathrm{Pb}$ dating are used. According to the tests and analysis results, Geochemical shows major elements of $w\left(\mathrm{SiO}_{2}\right) 64.7 \% \sim 77.41 \%$ (> $67 \%$ ), and $A / C N K ~ 0.889 ~ 1.234$. The zircon age of $K$-feldspar porphyritic granite is $838.8 \pm 6 \mathrm{Ma}$. Finally, infer the forming environment of K-feldspar porphyritic granite that magmatic activity should have been started since $838 \mathrm{Ma}$, related to postcollisional lithospheric delamination and upwelling of hot asthenosphere, and the tectonic environment of depressurization and warming.
\end{abstract}

Keywords-component; formation environment; K-feldspar; granite; E-Mount; LA- ICP-MS U-Pb

\section{INTRODUCTION}

E-Mount granite Pluton which rocky outcropping is about $200 \mathrm{~km}^{2}$ is located at southernmost Kang Dian axis in southwestern margin of the Yangtze Block. There are two rock types, commonly involvs (a)an early quartz diorite and granodiorite, and (b) a later K-feldspar porphyritic granit , which is the dominant rock type cropping out almost $180 \mathrm{~km}^{2}$.

Predecessors have done many studies of E-Mount granite Pluton. But there is no consensus information age as the previous backward analysis technics. This paper focus on the formation environme such as Chronology and Genesis of Kfeldspar porphyritic granit by analyzing new LA-ICP-MS zircon $\mathrm{U}-\mathrm{Pb}$ ages and geochemical features.

\section{GEOCHRONOLOGY}

So far, the ages of $818 \pm 10 \mathrm{Ma}$ [1] and $828 \pm 21 \mathrm{Ma}$ [2] have been the more credible formation time of E-Mount granite, based on methods of SHRIMP zircon U-Pb method and zircon and monazite $\mathrm{U}-\mathrm{Pb}$ dilution method respectively.

In this study, Samples $\mathrm{D}_{1-2}$ of $\mathrm{K}$-feldspar porphyritic granit for $\mathrm{U}-\mathrm{Pb}$ analysis were from $\mathrm{FaWu}$ village in the middle of Pluton(Table1). The work of Zircon separation and analysis experiment have been done by Institute of Geology and Mineral Resources Survey, Langfang, Hebei region and State Key Laboratory of Continental Dynamics, Northwest University, respectively. Test analysis method has been reported by Li Huaikun[3].

Due to varying degrees of recrystallization or $\mathrm{Pb}$ loss of zirconium in thermal event, we choose 3 biggest zircons with clearest oscillatory rings. From the three analyses of 3 zircons, they have $\mathrm{Th}=302 \sim 309 \mathrm{ppm}, \mathrm{U}=705 \sim 840 \mathrm{ppm}$, and rations of molecular $\mathrm{Th} / \mathrm{U}=0.4 \sim 0.5(>0.1)$, suggesting from magma[4].

For these 3 analyses, ratios of ${ }^{238} \mathrm{U} /{ }^{206} \mathrm{~Pb}$ shows age from $835 \sim 881 \mathrm{Ma}, \quad \mathrm{In}^{207} \mathrm{~Pb} /{ }^{235} \mathrm{~Pb}-{ }^{238} \mathrm{U} /{ }^{206} \mathrm{~Pb}$ concordia diagram using isoplot4.5 (Figure 1), zircons are in agreement and yield a concordant ages of $838.8 \pm 6 \mathrm{Ma}(2 \sigma, \mathrm{MSWD}=0.63)$. But one analyse of zircon $\mathrm{D}_{1-2-3}$ is discordant with ${ }^{207} \mathrm{~Pb} /{ }^{206} \mathrm{~Pb}$ and ${ }^{238} \mathrm{U} /{ }^{206} \mathrm{~Pb}$, indicating loss of radiogenic $\mathrm{Pb}$ from the analysed site.

\section{CHEMICAL COMPOSITIONS OF K-FELDSPAR PORPHYRITIC GRANIT}

This paper measured chemical compositions of 2 Samples and the other 29 samples have been compiled from the literature[5]. All samples plot in the granite and alkali granite field in the Q-A-P diagram. The Concentrations (in wt $\%$ ) of $\mathrm{SiO}_{2}(64.7 \sim 77.41), \mathrm{K}_{2} \mathrm{O}(3.375 \sim 5.38)$ span wide ranges. In $\mathrm{SiO}_{2}-\mathrm{K}_{2} \mathrm{O}$ diagram, most samples plot in $\mathrm{K}$ calc-alkaline series, some plot in Shoshonitic series. The ratio of $\mathrm{K}_{2} \mathrm{O} / \mathrm{NaO}$ is 1.06 2.3 suggesting that intrusions is characterized by potassium.

All samples of E-Mount granite with $\mathrm{A} / \mathrm{CNK}$ ratios 0.889 1.234, plot in metaluminous - peraluminous field especially near 1.1 in $\mathrm{A} / \mathrm{CNK}-\mathrm{A} / \mathrm{NK}$ diagram, possibly indicative of mixed I- and S-type compositions. These samples also have a wide range in $\mathrm{Rb}$ (57.2 352ppm), $\operatorname{Sr}(93.6 \sim 963 \mathrm{ppm})$ and $\mathrm{Ba}(253 \sim 2641 \mathrm{ppm})$. On the ORGnormalised spidergram, the K-feldspar porphyritic granit are characterised by strong enrichment in $\mathrm{K}, \mathrm{Rb}, \mathrm{La}$ and $\mathrm{Th}$ and pronounced negative anomalies of $\mathrm{Ba}, \mathrm{Nb}, \mathrm{Sr}, \mathrm{P}, \mathrm{Ti}$, relative to neighbouring elements. Furthermore, they have generally similar REE patterns showing variable LREE-enrichment and moderate Eu anomalies.

\section{DISCUSSION}

\section{A. Genesis}

The petrographic, mineralogical, and chemical characteristics, such as initial $\varepsilon N d(t)=-6.52 \sim-8.43, T_{2 \mathrm{DM}}$ model ages $2.01 \sim 2.19 \mathrm{Ga}$, weighted average $2.1 \mathrm{Ga}[1]$, resulting from granitic magmas in E-Mount Pluton is subdivided into KCG type[6], suggesting that nature of the source is main correspond to crustal origin of the magmas at the age of $2.1 \mathrm{Ga}$.

$$
\mathrm{Al}_{2} \mathrm{O}_{3}+\mathrm{MgO}+\mathrm{FeO}^{\mathrm{T}}+\mathrm{TiO}_{2}>15
$$

and $\mathrm{Al}_{2} \mathrm{O}_{3} /\left(\mathrm{MgO}+\mathrm{FeO}^{\mathrm{T}}+\mathrm{TiO}_{2}\right)<5$ illustrates that samples plot in the basaltic magmas and metagreywacke field and some in 
overlapping areas of them, suggesting that these magmas may derive from hybrid magmas, formed by reaction of basaltic melts with metagreywacke of supracrustal origin. [7]

According to the experiments of Rapp, R. P.,[8], the basaltic melt may have $\mathrm{Mg}^{\#}<0.4$, but when the mantle components involved, it may have $\mathrm{Mg}^{\#}>0.4$. K-feldspar granit from E-Mount Pluton have $\mathrm{Mg}^{\sharp}=0.2 \sim 1.1$, indicated mantle not only provides heat, also contributions to the origin of granitic magmas.

\section{B. Tectonic Environment}

All date from K-rich granitoids plot exclusively within the "post-collision granitoid" field on the $\mathrm{Y}+\mathrm{Nb}$ versus $\mathrm{Rb}$ diagram.

The relative temperatures of SP granite melts are reflected in their $\mathrm{Al}_{2} \mathrm{O}_{3} / \mathrm{TiO}_{2}$ ratios. Hot $\left(>875^{\circ} \mathrm{C}\right) \mathrm{SP}$ granite melts with low $(<100) \mathrm{Al}_{2} \mathrm{O}_{3} / \mathrm{TiO}_{2}$ ratios[9]. Granit from E-Mount Pluton have $\mathrm{Al}_{2} \mathrm{O}_{3} / \mathrm{TiO}_{2}=22 \sim 86$. Like in low-pressure and hightemperature collisional orogens, Crustal anatexis was related to post-collisional lithospheric delamination and upwelling of hot asthenosphere. In comparison, Chemical compositions of postcollisional granites in E-Mount may be in the tectonic environment of depressurization and warming.

\section{CONCLUSION}

The best estimate of the crystallisation age of K-feldspar porphyritic granit is between $818 \sim 838 \mathrm{Ma}$, which supporting the viewpoint that E-Mount granite Pluton formed in Jinning epoch.

TABLE I. LA-ICP-MS U-Pb ANALYTICAL DATAS FOR ZIRCONS FROM E-MOUNT (FAWU)

\begin{tabular}{|c|c|l|l|l|}
\hline \multirow{2}{*}{$\begin{array}{c}\text { Grain } \\
\mathbf{D}_{1-2}\end{array}$} & \multicolumn{4}{|c|}{ Zircon number } \\
\cline { 2 - 5 } & unit & \multicolumn{1}{|c|}{$\mathbf{1}$} & \multicolumn{1}{|c|}{$\mathbf{2}$} \\
\hline${ }^{238} \mathrm{U}$ & $\mathrm{ppm}$ & 765 & 840 & 705 \\
\hline${ }^{232} \mathrm{Th}$ & $\mathrm{ppm}$ & 302 & 338 & 369 \\
\hline $\mathrm{TU} / \mathrm{U}$ & $/$ & 0.4 & 0.4 & 0.5 \\
\hline \multirow{2}{*}{${ }^{207} \mathrm{~Pb} /{ }^{206} \mathrm{~Pb}$} & $/$ & 0.0707 & 0.0627 & 0.1551 \\
\cline { 2 - 5 } & $( \pm 1 \delta)$ & 0.0026 & 0.0021 & 0.0142 \\
\hline \multirow{2}{*}{${ }^{207} \mathrm{~Pb} /{ }^{235} \mathrm{U}$} & $/$ & 1.3667 & 1.2014 & 3.2058 \\
\cline { 2 - 5 } & $( \pm 1 \delta)$ & 0.0499 & 0.0379 & 0.324 \\
\hline \multirow{2}{*}{${ }^{206} \mathrm{~Pb} /{ }^{238} \mathrm{U}$} & $/$ & 0.1397 & 0.1382 & 0.1465 \\
\cline { 2 - 5 } & $( \pm 1 \delta)$ & 0.0015 & 0.0015 & 0.0023 \\
\hline \multirow{2}{*}{${ }^{207} \mathrm{~Pb} /{ }^{235} \mathrm{U}$} & age $(\mathrm{Ma})$ & 875 & 801 & 1459 \\
\cline { 2 - 5 } & $( \pm 1 \delta)$ & 21 & 17 & 78 \\
\hline \multirow{2}{*}{${ }^{206} \mathrm{~Pb} /{ }^{238} \mathrm{U}$} & age $(\mathrm{Ma})$ & 843 & 835 & 881 \\
\cline { 2 - 5 } & $( \pm 1 \delta)$ & 9 & 9 & 13 \\
\hline
\end{tabular}

a. Data is tested in Wuhan geological survey center of China Geological Survey

Nature of the source is main correspond to crustal origin of the magmas, derived from hybrid magmas, formed by reaction of basaltic melts with metagreywacke of supracrustal origin and had continuous evolution characteristics.

Since $838 \mathrm{Ma}$, Magmatic activity should have been started, related to post-collisional lithospheric delamination and upwelling of hot asthenosphere, and the tectonic environment of depressurization and warming.

TABLE II. COMPOSITIONS OF GRANITES

\begin{tabular}{|c|c|c|}
\hline \multirow{2}{*}{ Element } & \multicolumn{2}{|c|}{ Sample } \\
\hline & $D_{1-1}$ & $D_{1-2}$ \\
\hline \multicolumn{3}{|c|}{ Major elements (wt.\%) } \\
\hline $\mathrm{SiO}_{2}$ & 64.74 & 74.35 \\
\hline $\mathrm{Al}_{2} \mathrm{O}_{3}$ & 15.18 & 14.08 \\
\hline $\mathrm{Fe}_{2} \mathrm{O}_{3}$ & 0.492 & 0.304 \\
\hline $\mathrm{FeO}$ & 4.64 & 0.776 \\
\hline $\mathrm{CaO}$ & 2.64 & 0.432 \\
\hline $\mathrm{MgO}$ & 1.86 & 0.033 \\
\hline $\mathrm{K}_{2} \mathrm{O}$ & 3.37 & 5.38 \\
\hline $\mathrm{Na}_{2} \mathrm{O}$ & 3.18 & 3.94 \\
\hline $\mathrm{TiO}_{2}$ & 0.622 & 0.047 \\
\hline $\mathrm{P}_{2} \mathrm{O}_{5}$ & 0.193 & 0.246 \\
\hline $\mathrm{MnO}$ & 0.082 & 0.016 \\
\hline \multicolumn{3}{|c|}{ Ratios } \\
\hline Q & 30.17 & 22.85 \\
\hline A & 64.83 & 37.93 \\
\hline $\mathrm{P}$ & 1.1 & 22.54 \\
\hline $\mathrm{A} / \mathrm{CNK}$ & 1.11 & 1.076 \\
\hline (DI) & 71.12 & 95.56 \\
\hline AR & 2.16 & 4.59 \\
\hline$\sigma 43$ & 1.92 & 2.77 \\
\hline $\mathrm{K}_{2} \mathrm{O} / \mathrm{Na}_{2} \mathrm{O}$ & 1.06 & 1.37 \\
\hline $\mathrm{Al}_{2} \mathrm{O}_{3} / \mathrm{TiO}_{2}$ & 24.41 & 299.57 \\
\hline \multicolumn{3}{|c|}{ Trace elements (ppm) } \\
\hline $\mathrm{Rb}$ & 57.2 & 352 \\
\hline $\mathrm{Sr}$ & 400 & 104 \\
\hline $\mathrm{Ba}$ & 1060 & 253 \\
\hline \multicolumn{3}{|c|}{ Ratios } \\
\hline $\mathrm{Rb} / \mathrm{sr}$ & 0.143 & 3.385 \\
\hline $\mathrm{Rb} / \mathrm{Ba}$ & 0.054 & 1.391 \\
\hline
\end{tabular}

Datas are tested in Wuhan geological survey center of China Geological Survey 


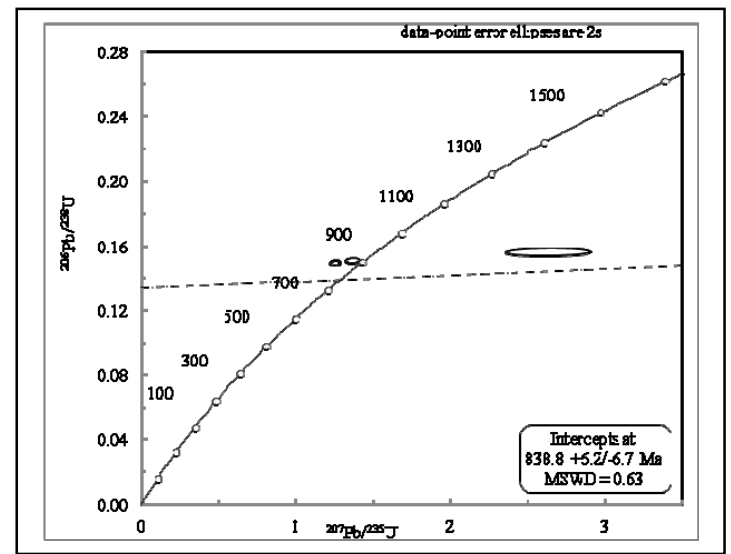

FIGURE I. ZIRCON u-Pb CONCORDIA DIAGRAM OF ESHAN GRANITE

zircons are in agreement and yield a concordant ages of $838.8 \pm 6 \mathrm{Ma}(2 \sigma, \mathrm{MSWD}=0.63)$. But one analyse of zircon $\mathrm{D}_{1-2-3}$ is discordant with ${ }^{207} \mathrm{~Pb} /{ }^{206} \mathrm{~Pb}$ and ${ }^{238} \mathrm{U} /{ }^{206} \mathrm{~Pb}$, indicating loss of radiogenic $\mathrm{Pb}$ from the analysed site.

\section{ACKNOWLEDGMENT}

Professor Shitao Zhang and Yunnan Nonferrous Geological Bureau 313 Team are thanked for helpful reviews.

\section{REFERENCES}

[1] Li, X. H., Li, Z. X., Ge, W., Zhou, H., Li, W., Liu, Y., \& Wingate, M. T. ,2003. Neoproterozoic granitoids in South China: crustal melting above a mantle plume at ca. $825 \mathrm{Ma}$ ?. Precambrian Research, 122(1), 45-83.

[2] Ma Guogan,1991.Isotopic age of the E-Mount Granite in Yunnan Province and its geological significance. Bull. Yichang Inst.Geol.Miner.Res.16:121-129 (in Chinese with English abstract).

[3] Li Huaikun, Geng Jianzhen, HaoShuang, \&Li Huimin.,2009. Zircon U$\mathrm{Pb}$ isotopic age determination multi receivers plasma mass spectrometry (LA-MC-ICPMS) using laser ablation. Acta Mineralogica Sinica, 6006,29(1),01. (in Chinese with English abstract).

[4] Williams, I. S., Buick, I. S., \& Cartwright, I.,1996. An extended episode of early Mesoproterozoic metamorphic fluid flow in the Reynolds Range, central Australia*.Journal of Metamorphic Geology, 14(1), 29-47.

[5] Xue Xihui,Cai Zhongbo,Xiong jiayong. ,1986.Questions about the era of Yunnan Asan granite [J]. Acta Petrologica Sinica, 2(1) (in Chinese with English abstract)

[6] Barbarin, B.,1990. Granitoids: main petrogenetic classifications in relation to origin and tectonic setting. Geological Journal, 25(3 - 4), 227238.

[7] Douce, A. E. P. ,1999. What do experiments tell us about the relative contributions of crust and mantle to the origin of granitic magmas?.Geological Society, London, Special Publications, 168(1), 5575.

[8] Rapp, R. P., \& Watson, E. B. ,1995. Dehydration melting of metabasalt at 8-32 kbar: implications for continental growth and crust-mantle recycling. Journal of Petrology, 36(4), 891-931.

[9] Sylvester, P. J., 1998. Post-collisional strongly peraluminous granites. Lithos, 45(1), 29-44. 